\title{
Incidence and Outcome of Reintubation in the Postanesthesia Care Unit: a Single-center, Retrospective, Observational Matched Cohort Study in China
}

\author{
Shangkun Liu \\ Tongji Hospital of Tongji Medical College of Huazhong University of Science and Technology \\ Ying Dong \\ Tongji Hospital of Tongji Medical College of Huazhong University of Science and Technology \\ Li Wan \\ Tongji Hospital of Tongji Medical College of Huazhong University of Science and Technology \\ Ailin Luo \\ Tongji Hospital of Tongji Medical College of Huazhong University of Science and Technology \\ Hong Chen \\ Tongji Hospital of Tongji Medical College of Huazhong University of Science and Technology \\ Hui Xu ( $\sim$ huixu@tjh.tjmu.edu.cn ) \\ Tongji Hospital of Tongji Medical College of Huazhong University of Science and Technology
}

\section{Research}

Keywords: general anesthesia, postanesthesia care unit, reintubation after planned extubation

Posted Date: November 8th, 2021

DOI: https://doi.org/10.21203/rs.3.rs-1030867/v1

License: (c) (i) This work is licensed under a Creative Commons Attribution 4.0 International License. Read Full License 


\section{Abstract}

Background囚 Reintubation after planned extubation (RAP) is a serious adverse event. This study aimed to determine the rate and impact of RAP on postoperative course and hospitalization outcomes.

Methods $₫$ Of the 121,965 patients in the PACU, 14 patients with RAP were included in this retrospective, single-center, 1:2 matched cohort study in China from January 1, 2017 to December 31, 2019. Duration of PACU stay, postoperative time in the hospital, inpatient healthcare costs, and outcome of hospitalization were compared between the RAP and matched groups.

Results $\$ The rate of RAP occurrence was $0.0115 \%$. After propensity score matching, there were no statistically significant differences in age, sex, body mass index, emergency operation, surgical classification, American Society of Anesthesiologists physical status, and the durations of anesthesia and the procedure between the two groups. Duration of PACU stay, length of postoperative stay, and inpatient healthcare costs significantly differed between the RAP and matched groups $(P<0.01$ for all). The percentage of patients in whom discharge from the PACU was prolonged was significantly higher in the RAP group than in the matched group $(92.86 \%$ vs.714\%), with an odds ratio of $29.87(95 \% \mathrm{Cl}=14.00$ to $2040.54 ; P<0.001)$ after matching.

Conclusions $\rrbracket$ RAP in the PACU had low incidence but was associated with life-threatening and serious complications, increased incidence of prolonged discharge, prolonged PACU and postoperative hospital stay, increased inpatient healthcare costs, and unanticipated intensive care unit admission. Hypoxemia, airway obstruction, dyspnea, respiratory depression, confusion, asthma, chest tightness, pain, hemorrhage, or agitation could be the risk factor for RAP. The appropriate time for tracheal extubation and monitoring in PACU can effectively prevent the occurrence of reintubation and improve the prognosis of patients.

\section{Background}

Admission to the postanesthesia care unit (PACU)had been the key for patient recovery after an operation ${ }^{1}$. Adverse respiratory events comprise one of the main critical events in the PACU ${ }^{2}$, with a reported incidence rate of $6-55 \%$ of all complications ${ }^{1,3,4}$. Reintubation of a surgical patient is a serious adverse respiratory event ${ }^{5,6}$. Based on published literature, the incidence of reintubation after planned extubation(RAP) in the PACU was from $0.0103-0.068 \%{ }^{6-10}$, with an incidence of $0.069 \%$ in China ${ }^{11}$.

RAP after surgery was reported to increase the number of unexpected intensive care unit (ICU) admission, length of ICU and hospital stay, duration of full ventilatory support, time to PACU discharge, rates of adverse cardiac events and ventilator-associated pneumonia, morbidity, mortality, cost, and staff demands ${ }^{5-7,10,12-16}$. RAP is an identifiable event and an outcome marker for quality improvement of post-operative course ${ }^{17}$. In China, RAP has served as a routine anesthesia quality indicator during the perioperative period. Therefore, a very high reintubation rate could represent low quality care and may negatively impact patient outcomes.

In general, immediate extubation in the postoperative period had been the standard and is a safe practice. However, RAP after surgery would be necessary in cases that develop events, such as respiratory failure, hypoxia, hypercapnia, and so on ${ }^{9}$. However, untilnow, detailed information on the outcomes of RAP in the PACU had been scarce. We aimed to determine the rate of RAP and evaluated its impact on duration of PACU and postoperative hospital stays, inpatient healthcare costs, and hospitalization outcomes.

\section{Materials And Methods}

The Strengthening the Reporting of Observational Studies in Epidemiology checklist for observational studies was used to guide the methods of this study and the structure of this manuscript. This was a matched cohort study that was conducted using a retrospectively collected database.

The study was carried out in Wuhan City, China at a general public university hospital with 62 clinical departments, 99 surgical rooms, and 38 beds in the PACU. The total number of operations performed in this hospital is more than $90,000 /$ year. The study was approved by the hospital ethics committee and was deemed that written patient consent was not required. The adverse events, including RAP, in all patients in the PACU were recorded on a standardized form in a database by pre-trained qualified nurses and/or anesthesiologists at the time of care from January 1, 2017 to December 31, 2019.

Data, including patient demographic and surgical and anesthesia parameters, were obtained from the anesthesia information system. Adverse events management and duration of PACU stay were also documented. For three years, all collected data were filed in a computer every day and were summarized and analyzed every month. Data, such as demographics, airway, oxygen saturation, consciousness, treatment, vital signs, and fast-track criteria scores, were recorded for all patients in the PACU. The first part contained preoperative and intraoperative data, which were entered into the database by the anesthesiologists involved in the patients' intraoperative care from the time of PACU admission. The second part were recorded by nurse and comprised postoperative data from the PACU to the ward or ICU. The third part were recorded by the surgeons and/ or surgical nurses and comprised postoperative data. The criteria for tracheal extubation in the operating room(OR) and the timing of transfer to the PACU were the responsibility of the anesthesiologist.

RAP was defined as repeat endotracheal intubation in the PACU after planned extubation of the initial endotracheal intubation for general anesthesia or combined general anesthesia other than that performed in the operating room. Patients without RAP during the PACU stay were designated as the matched group, whereas those with RAP during the PACU stay were designated as the RAP group. No RAP cases were missed, because all reintubation procedures were performed in the PACU. Patients on mechanical ventilation before the operation, those who were intubated upon PACU admission after the operation, and those who were admitted directly to a ward or ICU were excluded. The present study had a retrospective, matched cohort design, with a 1:2 match ratio for analysis. 
All continuous variables were described as mean (standard deviation) if they followed a normal distribution or as quartiles if they followed a nonnormal distribution. T-test was applied to variables that fit a normal distribution, whereas the nonparametric Mann-Whitney $U$ test was applied to variables that had a nonnormal distribution. Standard Chi-square test was applied to categorical variables, which were depicted as counts or percentages.

In order to have an accurate comparison of the net impact of RAP in the PACU,1:2 propensity score matching (PSM) of the two groups was performed using eight factors. Patients were selected into the RAP or matched group in pairs of comparable characteristics. The matching criteria were set by logistic regression on age, sex, BMI, durations of anesthesia and the procedure, American Society of Anesthesiologists (ASA) physical status, operation procedure, and surgical classification on RAP condition with a caliper. The maximum tolerated difference for matching was set to 0.000001 .

Statistical tests were performed using SPSS25 with PSM extension. All reported P values were two-sided, and statistical significance was set at a P value of $<0.05$ for all reported results.

\section{Results}

During the three-year retrospective study period, 121,965 patients underwent procedures under general anesthesia and stayed in the PACU from the OR. As shown in Table 1, there were 14 RAP cases in the PACU; therefore, the incidence of reintubation was 1.15 in $10,000(0.0115 \%)$ anesthesia procedures.

Table 1

Reintubation after planned extubation, incidence and percentages by year

\begin{tabular}{|llcl|}
\hline \multicolumn{4}{|c|}{ Reintubation after planned extubation, incidence and percentages by year } \\
\hline & Patients admitted to PACU(N) & Reintubations ( $\mathbf{n})$ & Percent of reintubations(\%) \\
\hline 2017 & 35,447 & 3 & 0.0085 \\
\hline 2018 & 40,373 & 4 & 0.0099 \\
\hline 2019 & 46,145 & 7 & 0.0152 \\
All years & 121,965 & 14 & 0.0115 \\
\hline Abbreviation: PACU, Postanesthesia Care Unit & \\
\hline
\end{tabular}

The detailed clinical characteristics of the RAP cases are presented in Table 2. Among the 14 cases of RAP, the type of surgery was urinary in 2 (14.29\%), cardiothoracic in 5 (35.71\%), bone in 3 (21.43\%), ENT in 1 (7.14\%), general surgery in 2 (14.29\%), and neurosurgery in 1 (7.14\%). The main reasons for RAP were atelectasis in 1 (7.14\%), respiratory depression in 8 (57.14\%), asthma in 2 (14.29\%), hemorrhage in 2 (14.29\%), hemorrhage and aspiration in 1 (7.14\%). The main reasons for respiratory depression were residual neuromuscular blockade in $3(21.43 \%)$, respiratory insufficiency associated with opiums in 6 (42.86\%). Nine (64.29\%) patients had unplanned transfer to the ICU. The patients were kept intubated after their emergent reintubation for a mean of 2.22 hours (IQR,1.0-13.97hours). Three (21.43\%) patients had a pulmonary infection. Five (35.71\%) patients were extubated in the PACU. The two (14.29\%) patients have died with complications in the ICU, one (7.14\%) of which had reoperation. The 11(78.57\%) RAP cases were cured. One (7.14\%) patient discharged against medical advice. One (7.14\%) patient required an emergency surgical airway after reintubation. 
Table 2-1

Clinical characteristics with RAP

\begin{tabular}{|c|c|c|c|c|c|c|c|c|c|c|c|}
\hline Patient & Sex & $\begin{array}{l}\text { Age } \\
\text { (year) }\end{array}$ & $\begin{array}{l}\mathrm{BMI} \\
\mathrm{kg} / \mathrm{m}^{2}\end{array}$ & $\begin{array}{l}\text { ASA } \\
\text { physical } \\
\text { status }\end{array}$ & $\begin{array}{l}\text { Operation } \\
\text { procedure }\end{array}$ & SC & Comorbiditties & $\begin{array}{l}\text { Surgical } \\
\text { Specialty }\end{array}$ & $\begin{array}{l}\text { Duration of } \\
\text { anaesthesia } \\
\text { (min) }\end{array}$ & $\begin{array}{l}\text { Duration } \\
\text { of } \\
\text { procedure } \\
\text { (min) }\end{array}$ & $\begin{array}{l}\text { Duratior } \\
\text { of PACU } \\
\text { stay(mir }\end{array}$ \\
\hline patient & male & 60 & 28.55 & प & elective & 4 & renal cyst & $\begin{array}{l}\text { urinary } \\
\text { surgery }\end{array}$ & 269 & 218 & 64 \\
\hline patient & female & 28 & 21.48 & प & elective & 2 & no & neurosurgery & 318 & 265 & 90 \\
\hline $\begin{array}{l}\text { patient } \\
3\end{array}$ & female & 60 & 18.43 & प & elective & 4 & no & $\begin{array}{l}\text { cardiothoracic } \\
\text { surgery }\end{array}$ & 191 & 159 & 110 \\
\hline $\begin{array}{l}\text { patient } \\
4\end{array}$ & female & 63 & 32.87 & प & elective & 3 & $\begin{array}{l}\text { diabetes,cerebral } \\
\text { infarction }\end{array}$ & $\begin{array}{l}\text { general } \\
\text { surgery }\end{array}$ & 195 & 154 & 73 \\
\hline $\begin{array}{l}\text { patient } \\
5\end{array}$ & female & 65 & 24.34 & प & elective & 4 & asthma & bone surgery & 165 & 110 & 36 \\
\hline $\begin{array}{l}\text { patient } \\
6\end{array}$ & female & 68 & 22.67 & प & elective & 3 & $\begin{array}{l}\text { hypertension,diabetes, } \\
\text { hyperlipemia,rheumatism }\end{array}$ & $\begin{array}{l}\text { cardiothoracic } \\
\text { surgery }\end{array}$ & 235 & 160 & 227 \\
\hline patient & male & 75 & 24.77 & प & emergency & 3 & $\begin{array}{l}\text { hypertension, } \\
\text { tuberculosis }\end{array}$ & $\begin{array}{l}\text { cardiothoracic } \\
\text { surgery }\end{array}$ & 125 & 75 & 137 \\
\hline $\begin{array}{l}\text { patient } \\
8\end{array}$ & male & 11 & 16.67 & प & elective & 3 & no & $\begin{array}{l}\text { general } \\
\text { surgery }\end{array}$ & 163 & 95 & 65 \\
\hline $\begin{array}{l}\text { patient } \\
9\end{array}$ & male & 58 & 22.86 & प & elective & 3 & no & bone surgery & 177 & 150 & 74 \\
\hline $\begin{array}{l}\text { patient } \\
10\end{array}$ & female & 47 & 23.44 & प & elective & 3 & hematuria & $\begin{array}{l}\text { cardiothoracic } \\
\text { surgery }\end{array}$ & 196 & 130 & 120 \\
\hline $\begin{array}{l}\text { patient } \\
11\end{array}$ & female & 60 & 21.64 & प & elective & 3 & thyroid cancer & $\begin{array}{l}\text { cardiothoracic } \\
\text { surgery }\end{array}$ & 201 & 142 & 66 \\
\hline $\begin{array}{l}\text { patient } \\
12\end{array}$ & male & 64 & 24.80 & प & emergency & 4 & no & bone surgery & 320 & 290 & 100 \\
\hline $\begin{array}{l}\text { patient } \\
13\end{array}$ & male & 65 & 23.39 & प & elective & 3 & no & ENT & 254 & 186 & 140 \\
\hline $\begin{array}{l}\text { patient } \\
14\end{array}$ & female & 64 & 29.30 & प & elective & 4 & hypertension & $\begin{array}{l}\text { urinary } \\
\text { surgery }\end{array}$ & 289 & 228 & 151 \\
\hline
\end{tabular}


Table 2-2

Clinical characteristics with RAP

\begin{tabular}{|c|c|c|c|c|c|c|c|}
\hline Patient & $\begin{array}{l}\text { Care unit of } \\
\text { postoperative }\end{array}$ & $\begin{array}{l}\text { Oxygenation state after } \\
\text { reextubation }\end{array}$ & Complications & $\begin{array}{l}\text { Duration of } \\
\text { reintubation } \\
\text { (hr) }\end{array}$ & $\begin{array}{l}\text { Postoperative } \\
\text { pneumonia }\end{array}$ & $\begin{array}{l}\text { Length of } \\
\text { postoperative } \\
\text { stay(days) }\end{array}$ & $\begin{array}{l}\text { Discharge } \\
\text { outcome }\end{array}$ \\
\hline patient & ICU & $\begin{array}{l}\mathrm{SPO}_{2}>95 \% \text { with low-flow } \\
\text { nasal cannula }\end{array}$ & no & 25.3 & yes & 12 & cure \\
\hline \multirow[t]{2}{*}{$\begin{array}{l}\text { patient } \\
2\end{array}$} & \multirow[t]{2}{*}{ ICU } & \multirow[t]{2}{*}{$\begin{array}{l}\mathrm{SPO}_{2}>95 \% \text { with low-flow } \\
\text { nasal cannula }\end{array}$} & \multirow[t]{2}{*}{ symptom increased } & \multirow[t]{2}{*}{16.5} & \multirow[t]{2}{*}{ no } & \multirow[t]{2}{*}{26} & $\begin{array}{l}\text { discharge } \\
\text { against }\end{array}$ \\
\hline & & & & & & & $\begin{array}{l}\text { medical } \\
\text { advice }\end{array}$ \\
\hline $\begin{array}{l}\text { patient } \\
3\end{array}$ & ICU & $\begin{array}{l}\mathrm{SPO}_{2}>95 \% \text { with low-flow } \\
\text { nasal cannula }\end{array}$ & no & 1.0 & no & 14 & cure \\
\hline $\begin{array}{l}\text { patient } \\
4\end{array}$ & general ward & $\begin{array}{l}\mathrm{SPO}_{2}>95 \% \text { with low-flow } \\
\text { nasal cannula }\end{array}$ & no & 1.0 & no & 14 & cure \\
\hline $\begin{array}{l}\text { patient } \\
5\end{array}$ & ICU & $\begin{array}{l}\mathrm{SPO}_{2}>95 \% \text { with low-flow } \\
\text { nasal cannula }\end{array}$ & no & 2.0 & no & 9 & cure \\
\hline $\begin{array}{l}\text { patient } \\
6\end{array}$ & ICU & $\begin{array}{l}90 \%<\mathrm{SPO}_{2}<94 \% \text { with } \\
\text { high-flow mask }\end{array}$ & no & 21.8 & no & 22 & cure \\
\hline $\begin{array}{l}\text { patient } \\
7\end{array}$ & ICU & / & $\begin{array}{l}\text { massive hemorrhage and } \\
\text { secondary procedures }\end{array}$ & 1.8 & no & 0 & die \\
\hline \multirow{2}{*}{$\begin{array}{l}\text { patient } \\
8\end{array}$} & \multirow[t]{2}{*}{ ICU } & \multirow{2}{*}{$\begin{array}{l}60 \%<\mathrm{SPO}_{2}<90 \% \text { with } \\
\text { invasive ventilation }\end{array}$} & bleeding in multiple & \multirow[t]{2}{*}{9.3} & \multirow[t]{2}{*}{ yes } & \multirow[t]{2}{*}{1} & \multirow[t]{2}{*}{ die } \\
\hline & & & body parts & & & & \\
\hline $\begin{array}{l}\text { patient } \\
9\end{array}$ & general ward & $\begin{array}{l}\mathrm{SPO}_{2}>95 \% \text { with low-flow } \\
\text { nasal cannula }\end{array}$ & no & 1.0 & no & 9 & cure \\
\hline $\begin{array}{l}\text { patient } \\
10\end{array}$ & general ward & $\begin{array}{l}\mathrm{SPO}_{2}>95 \% \text { with low-flow } \\
\text { nasal cannula }\end{array}$ & no & 1.0 & no & 15 & cure \\
\hline $\begin{array}{l}\text { patient } \\
11\end{array}$ & ICU & $\begin{array}{l}\mathrm{SPO}_{2}>95 \% \text { with low-flow } \\
\text { nasal cannula }\end{array}$ & no & 5.5 & no & 10 & cure \\
\hline $\begin{array}{l}\text { patient } \\
12\end{array}$ & ICU & $\begin{array}{l}\mathrm{SPO}_{2}>95 \% \text { with low-flow } \\
\text { nasal cannula }\end{array}$ & no & 13.1 & no & 7 & cure \\
\hline $\begin{array}{l}\text { patient } \\
13\end{array}$ & $\begin{array}{l}\text { OR with } \\
\text { intubation }\end{array}$ & $\begin{array}{l}\mathrm{SPO}_{2}>95 \% \text { with low-flow } \\
\text { nasal cannula }\end{array}$ & tracheotomy & 1.1 & yes & 26 & cure \\
\hline $\begin{array}{l}\text { patient } \\
14\end{array}$ & general ward & $\begin{array}{l}\mathrm{SPO}_{2}>95 \% \text { with low-flow } \\
\text { nasal cannula }\end{array}$ & no & 2.4 & no & 11 & cure \\
\hline
\end{tabular}

As shown in Table 3, the two groups had no significant differences in the demographic factors, such as age, sex, and BMI and in the operation procedure, surgical classification, ASA physical status, and durations of anesthesia and procedure. 
Table 3

Baseline date of patients before and after the matching

\begin{tabular}{|c|c|c|c|c|c|c|c|}
\hline & No.(\%) Without PSM & & & & No.(\%) With PSM & & \\
\hline & Total $(n=121965)$ & $\begin{array}{l}\text { Nonreintubated } \\
(\mathrm{n}=121951)\end{array}$ & RAP group $(n=14)$ & $\mathrm{P}$ & Total $(\mathrm{n}=42)$ & $\begin{array}{l}\text { Matched group } \\
(\mathrm{n}=28)\end{array}$ & RAP group $(n=14)$ \\
\hline Gender & & & & 0.719 & & & \\
\hline Female & 75383(61.81) & 75375(61.81) & $8(57.14)$ & & 25 & 17 & $8(57.14)$ \\
\hline Male & 46582(38.19) & 46576(38.19) & $6(42.86)$ & & 17 & 11 & $6(42.86)$ \\
\hline Age (year) & $46.00(33.00,56.00)$ & $46.00(33.00,56.00)$ & $61.50(55.25,65.00)$ & 0.002 & $60.00(49.25,66.50)$ & $56.50(47.75,69.00)$ & $61.50(55.25,65.00$ \\
\hline $\mathrm{BMI}\left(\mathrm{kg} / \mathrm{m}^{2}\right)$ & $22.77(20.55,25.10)$ & $22.77(20.55,25.10)$ & & 0.363 & $24.19 \pm 3.61$ & $24.32 \pm 3.36$ & $23.94 \pm 4.20$ \\
\hline Procedure & & & & 0.998 & & & \\
\hline Elective & 100157(82.12) & 100145(82.12) & 12(85.71) & & $38(90.48)$ & $26(92.86)$ & 12(85.71) \\
\hline Emergency & 21802(17.88) & 21800(17.88) & $2(14.29)$ & 0.998 & $4(9.52)$ & $2(7.14)$ & $2(14.29)$ \\
\hline $\begin{array}{l}\text { Surgical } \\
\text { classification }\end{array}$ & & & & 0.370 & & & \\
\hline 1 & $4595(3.77)$ & $4595(3.77)$ & $0(0)$ & & & & \\
\hline 2 & $24679(20.23)$ & 24678(20.24) & $1(7.14)$ & & $2(4.76)$ & $1(3.57)$ & $1(7.14)$ \\
\hline 3 & $55521(45.52)$ & $55513(45.52)$ & $8(57.14)$ & & $21(50.00)$ & $13(46.43)$ & $8(57.14)$ \\
\hline 4 & $37170(30.48)$ & $37165(30.48)$ & $5(35.71)$ & & $19(45.24)$ & $14(50.00)$ & $5(35.71)$ \\
\hline $\begin{array}{l}\text { ASA physical } \\
\text { status }\end{array}$ & & & & 0.003 & & & \\
\hline I & 41996(34.43) & 41996(34.44) & $0(0)$ & & $2(4.76)$ & $2(7.14)$ & $0(0)$ \\
\hline ॥ & 71729(58.81) & 71719(58.81) & $10(71.43)$ & & $26(61.90)$ & $16(57.14)$ & $10(71.43)$ \\
\hline III & $7822(6.41)$ & $7818(6.41)$ & $4(28.57)$ & & 14(33.33) & $10(35.71)$ & $4(28.57)$ \\
\hline$\square$ & $290(0.24)$ & $290(0.24)$ & $0(0)$ & & & & \\
\hline $\begin{array}{l}\text { Duration of } \\
\text { anaesthesia } \\
\text { (min) }\end{array}$ & $\begin{array}{l}140.00 \\
(93.00,205.00)\end{array}$ & $\begin{array}{l}140.00 \\
(93.00,205.00)\end{array}$ & $\begin{array}{l}198.50 \\
(174.00,274.00)\end{array}$ & 0.001 & $\begin{array}{l}186.50 \\
(135.75,186.50)\end{array}$ & $\begin{array}{l}165.00 \\
(121.50,268.75)\end{array}$ & $\begin{array}{l}198.50 \\
(174.00,274.00)\end{array}$ \\
\hline $\begin{array}{l}\text { Duration of } \\
\text { procedure } \\
\text { (min) }\end{array}$ & $\begin{array}{l}105.00 \\
(63.00,165.00)\end{array}$ & $\begin{array}{l}105.00 \\
(63.00,165.00)\end{array}$ & $\begin{array}{l}156.50 \\
(125.00,220.50)\end{array}$ & 0.007 & $\begin{array}{l}137.50 \\
(93.50,220.50)\end{array}$ & $\begin{array}{l}117.00 \\
(80.25,237.25)\end{array}$ & $\begin{array}{l}156.50 \\
(125.00,220.50)\end{array}$ \\
\hline
\end{tabular}

As shown in Table 4, the RAP and matched groups had significant differences in the duration of PACU stay [95mins(IQR,65.75-137.75mins) vs. 29.50mins(IQR,19.25-48.75mins)]; length of postoperative stay [11.50 days(IQR,8.50-16.75days) vs. 7.00 days(IQR,5.00-10.75days)]; and inpatient healthcare costs [\$10781.58(IQR, \$7344.52-15394.24) vs.\$5506.42(IQR, \$3744.12-10486.05)] ( $P<0.01$ for all). There was no difference between the two groups in terms of the duration of postoperative monitoring [16.96hrs(IQR,8.08-19.75hrs) vs. 18.75hrs(IQR,13.46-41.62hrs)].

Table 4

Clinical outcome of patients

\begin{tabular}{|c|c|c|c|c|}
\hline & Total( $(n=42)$ & Matched group $(n=28)$ & RAP group $(n=14)$ & $\mathbf{P}$ \\
\hline Duration of PACU stay(min) & $42.50(22.75,74.75)$ & $29.50(19.25,48.75)$ & $95.00(65.75,137.75)$ & $<0.001$ \\
\hline Length of stay(day) & $15.00(11.00,23.25)$ & $13.50(9.00,21.75)$ & $20.00(14.50,26.25)$ & 0.067 \\
\hline Length of postoperative stay(day) & $8.00(5.00,13.00)$ & $7.00(5.00,10.75)$ & $11.50(8.50,16.75)$ & 0.033 \\
\hline Duration of postoperative monitoring(hr) & $17.25(10.58,25.46)$ & $16.96(8.08,19.75)$ & $18.75(13.46,41.62)$ & 0.219 \\
\hline Inpatient healthcare costs $(\$)$ & $7266.21(4589.43,12014.48)$ & $5506.42(3744.12,10486.05)$ & $10781.58(7344.52,15394.24)$ & 0.010 \\
\hline Unanticipated ICU admission & $11(26.19)$ & $2(7.14)$ & $9(64.29)$ & $<0.001$ \\
\hline
\end{tabular}


The number of patients in whom discharge from the PACU was prolonged was significantly higher in the RAP group than in the matched group (92.86\% vs.714\%), with an odds ratio after matching of $29.87(95 \% \mathrm{Cl}=14.00$ to $2040.54 ; P<0.001)$.

\section{Discussion}

RAP in the PACU is a rare occurrence, with reported rates of $0.0103-0.069 \% 6,7,9-11,17$. Similar to previous reports, our study found a RAP incidence of $0.0115 \%$ for three years in the PACU. Unfortunately, we only studied the number of patients who received general anesthesia and did not know the number of patients who were initially intubated. Moreover, we found that the significant consequences of RAP were delayed PACU discharge, increased number of unexpected ICU admissions, longer durations of ICU stay postoperative stay, and increased hospital costs, and staff demands. As previouslyreported ${ }^{1,18,6}$, our results showed that RAP had a tendency to prolong hospital stay for three days and had severe implications, including increased morbidity and mortality, too. This retrospective, observational matched cohort study revealed the importance of PACU in the recovery phase of general anesthesia. The staffing and infrastructure of PACU need to be guaranteed, as well as ongoing education and quality assurance standards to ensure that the incidence of RAP can be reduced. In previous studies, reintubation occurred most frequently after airway, cardiac, and thoracic surgeries and after abdominal, neurosurgical, and head and neck procedures in the PACU ${ }^{5,6}$. In our study, the patients with RAP could underwent other operations, such as urinary surgery and bone surgery. The main factors of RAP were general anesthesia and patient's condition, except operative site. In this present study, 4(28.57\%) and 10(71.43\%) patients with RAP had ASA physical status III and II, respectively. RAP may occur in patients with relatively few comorbidities and in whom clinicians might not expect the occurrence of RAP, as reported previously 8,19

There were two hospital mortalities with fatal complications in this study. Nevertheless, reintubation remains an important issue because of its significant implications and consequences ${ }^{14}$. Admission to the PACU for RAP after general anesthesia implies life-threatening conditions, serious complications, higher cost, and increased staff demands $6,10,14$. The rate of unplanned transfer to the ICU in our study was higher, compared with the previously reported rate of other adverse events in the PACU ${ }^{20}$. Compared with our study, previous studies ${ }^{14,21}$ reported a higher rate $(73.3 \%)$ of postoperative respiratory complications that necessitated emergency ICU admission. Similar to previous studies ${ }^{14}$, our study had a $60 \%$ rate of unplanned ICU admission.

Similar to previous reports ${ }^{9,10}$, this study found that the risk factors for RAP were hypoxemia, airway obstruction, dyspnea, respiratory depression, confusion, asthma, chest tightness, pain, hemorrhage, and agitation. The median duration of reintubation was shorter in this study than in a previous study about RAP in the $I C U^{22}$. A previous study by Inget al ${ }^{14}$ reported that the average duration of reintubation was $2.4 \pm 1.9$ days (range, $0.5-7$ days) in the perioperative period. Early identification and determination of RAP could shorten the duration of reintubation. The appropriate time for tracheal extubation and monitoring in PACU can effectively prevent the occurrence of reintubation and improve the prognosis of patients.

Reducing the probability of reintubation can effectively shorten the time of unnecessary mechanical ventilation and the length of hospital stay ${ }^{7}$, thereby, reducing the burden of hospital work and waste of healthcare utilization.

There were a few limitations in this study. Despite our careful attempt to control for confounding factors, residual confounding factors may have been present, because PSM can only balance known confounding factors. Another major limitation of this study was that the date were derived from a self-reporting system.

\section{Conclusions}

In conclusion, the incidence of RAP in the PACU was quite low. However, RAP was associated with life-threatening and serious complications, increased the incidence of prolonged discharge and unanticipated ICU admission, prolonged PACU stay and postoperative stay, and increased inpatient healthcare costs and healthcare utilisation. However, the duration of postoperative monitoring remained unchanged. The risk factors for RAP could be hypoxemia, airway obstruction, dyspnea, respiratory depression, confusion, asthma, chest tightness, pain, hemorrhage, or agitation. RAP should be avoided as much as possible to improve the prognosis of patients and save medical resources.

\section{Abbreviations}

PACU, Postanesthesia Care Unit; RAP, Reintubation after planned extubation; ICU, Intensive care unit; OR, Operating room; PSM, Propensity Score Matching; BMI, Body Mass Index; ASA, American Society of Anesthesiologists; IQR, interquartile range; SC, Surgical classification

\section{Declarations}

\section{Ethics approval and consent to participate}

The study was performed in accordance with the ethical standards of the 1964 Declaration of Helsinki. As the study was observational, retrospective, and used existing, routinely collected data, informed consent was not required from the subjects. The study was approved by the Hospital Ethics Committee (TJIRB20170501).

\section{Consent for publication}


Availability of data and materials

The datasets generated and analyzed in the current study are available from the corresponding author on reasonable request.

\section{Competing interests}

The authors certify that there is no conflict of interest with any financial organization regarding the material discussed in the manuscript.

\section{Funding}

This research was funded by a grant from National Key R\&D Program of China (Grant 2020YFC2009002). The funding bodies played the roles in the interpretation of data and in writing the manuscript. This work was supported by the Department of Anaesthesiology, Tongji Hospital, Tongji Medical College, Huazhong University of Science and Technology, China.

\section{Authors' contributions}

Study design: Shangkun Liu and Hong Chen. Data acquisition and analysis: Ying Dong and Shangkun Liu. Data interpretation: Li Wan and Ailin Luo. Manuscript preparation: Shangkun Liu and Hui Xu. Manuscript revision: all authors. Final approval: all authors.

All authors have read and approved the final version of the manuscript.

\section{Acknowledgements}

The authors acknowledge Jing Chen for proofreading activity.

Participating Investigator: The authors acknowledge the qualified nurses and anesthesiologists of the PACU who collected data.

\section{References}

1. Liu S, Chen G, Yan B, Huang J, Xu H. Adverse Respiratory Events Increase Post-anesthesia Care Unit Stay in China: A 2-year Retrospective Matched Cohort Study. Current Medical Science. 2019;39(2):325-9.

2. Jeffrey L. Apfelbaum MDCC. Practice Guidelines for Postanesthetic Care An Updated Report by the American Society of Anesthesiologists Task Force on Postanesthetic Care. ANESTHESIOLOGY. 2013;96(3):742-52.

3. Tarrac SE. A Description of Intraoperative and Postanesthesia Complication Rates. J PERIANESTH NURS. 2006;21(2):88-96.

4. Siddiqui N, Arzola C, Teresi J, Fox G, Guerina L, Friedman Z. Predictors of desaturation in the postoperative anesthesia care unit: an observational study. J CLIN ANESTH. 2013;25(8):612-7.

5. Rujirojindakul P, Geater AF, McNeil EB, et al. Risk factors for reintubation in the post-anaesthetic care unit: a case-control study. BRIT J ANAESTH. 2012;109(4):636-42.

6. Haritos G, Smith CA, Haas RE, et al. Critical Events Leading to Endotracheal Reintubation in the Postanesthesia Care Unit: A Retrospective Inquiry of Contributory Factors. AANA journal. 2019 2019-01-01;87(1):59-63.

7. Peter J. Lee MM, Allison MacLennan M, Norah N. Naughton M, Michael O Reilly MM. An Analysis of Reintubations from a Quality Assurance Database of 152,000 Cases. J CLIN ANESTH. 2003;15(8):582-6.

8. Bruins SD, Leong PM, Ng SY. Retrospective review of critical incidents in the post-anaesthesia care unit at a major tertiary hospital. SINGAP MED J. 2017;58(8):497-501.

9. Ting P, Chou A, Yang M, Ho AC, Chang C, Chang S. Postoperative reintubation after planned extubation: A review of 137,866 general anesthetics from 2005 to 2007 in a Medical Center of Taiwan. Acta Anaesthesiologica Taiwanica. 2010;48(4):167-71.

10. Postoperative Reintubation at Postanesthesia Care Unit from 2010 to 2011 at a Teaching Hospital in Taiwan.

11. Siao-feng A, Tai-di Z, OU QH. Risk factors for postoperative reintubation in patients undergoing general anesthesia. Chin J Anesthesiol. 2013;33(12):142730.

12. Beverly A, Brovman EY, Malapero RJ, Lekowski RW, Urman RD. Unplanned Reintubation Following Cardiac Surgery: Incidence, Timing, Risk Factors, and Outcomes. J CARDIOTHOR VASC AN. 2016;30(6):1523-9.

13. Menon N, Joffe AM, Deem S, et al. Occurrence and Complications of Tracheal Reintubation in Critically III Adults. RESP CARE. 2012;57(10):1555-63.

14. Ing C, Chui I, Ohkawa S, Kakavouli A, Sun L. Incidence and causes of perioperative endotracheal reintubation in children: a review of 28208 anesthetics. PEDIATR ANESTH. 2013 2013-01-01;23(7):621-6.

15. De la Garza Ramos R, Passias PG, Schwab F, Bydon A, Lafage V, Sciubba DM. Incidence, Risk Factors, and Mortality of Reintubation in Adult Spinal Deformity Surgery. CLIN SPINE SURG. 2017 2017-01-01;30(7):E896-900.

16. Gao F, Yang L, He H, et al. The effect of reintubation on ventilator-associated pneumonia and mortality among mechanically ventilated patients with intubation: A systematic review and meta-analysis. HEART LUNG. 2016;45(4):363-71.

17. Karamanos E. Association of Unplanned Reintubation with Higher Mortality in Old, Frail Patients: A National Surgical Quality-Improvement Program Analysis. The Permanente Journal. 2016. 
18. Marquez-Lara A, Nandyala SV, Fineberg SJ, Singh K. Incidence, Outcomes, and Mortality of Reintubation After Anterior Cervical Fusion. SPINE. 2014;39(2):134-9.

19. Liu S, Wang Z, Xiong J, Wan L, Luo A, Wang X. Continuous Analysis of Critical Incidents for 92,136 Postanesthesia Care Unit Patients of a Chinese University Hospital. J PERIANESTH NURS. 2020.

20. Kluger MT, Bullock MFM. Recovery room incidents: a review of 419 reports from the Anaesthetic Incident Monitoring Study (AIMS). ANAESTHESIA. 2002 2002-01-01;57(11):1060-6.

21. Sudré ECM, de Batista PR, Castiglia YMM. Longer Immediate Recovery Time After Anesthesia Increases Risk of Respiratory Complications After Laparotomy for Bariatric Surgery: a Randomized Clinical Trial and a Cohort Study. OBES SURG. 2015;25(11):2205-12.

22. Miltiades AN, Gershengorn HB, Hua M, Kramer AA, Li G, Wunsch H. Cumulative Probability and Time to Reintubation in U.S. ICUs. CRIT CARE MED. 2017;45(5):835-42.

\section{Supplementary Files}

This is a list of supplementary files associated with this preprint. Click to download.

- renamed00be8.pdf 